\title{
Silica Microparticles Supported Gold and Copper Ferrite Nanoparticles: A Magnetically Recyclable Bimetallic Catalyst for Sonogashira Reaction
}

\author{
Mohammad Gholinejad, ${ }^{*[a]}{ }^{3}$ ahantab Ahmadi, ${ }^{[a]}$ Carmen Nájera* ${ }^{\star[b]}$
}

\begin{abstract}
Novel silica supported gold and copper ferrite nanoparticles (NPs) have been synthesized, characterized and used as a separable dual catalyst in Sonogashira type reaction. These $\mathrm{Au} \cdot \mathrm{CuFe}_{2} \mathrm{O}_{4} @$ Silica NPs show a high efficiency as catalyst in the alkynylation not only of aryl iodides but also aryl bromides. By using only $0.5 \mathrm{~mol} \%$ loading and $t$-BuOK as base in $N, N$ dimethylacetamide as solvent, aryl iodides react at $115^{\circ} \mathrm{C}$ in $1 \mathrm{~d}$, whereas for aryl bromides the cross-coupling takes place at $130{ }^{\circ} \mathrm{C}$ in $2 \mathrm{~d}$. The catalyst can be successfully recycled using an external magnet for four consecutive runs.
\end{abstract}

\section{Introduction}

Over the past few years, gold catalyzed organic transformations have attracted a great interest because of the well-recognized catalytic property of the gold. Oxidation of alcohols, ${ }^{1}$ direct arene functionalization, ${ }^{2}$ hydrogenation, ${ }^{3}$ oxycyclizations of alkynols and alkyndiols, ${ }^{4}$ cyclization of enynes, ${ }^{5}$ deoxygenation of epoxides to alkenes, ${ }^{6}$ and different coupling reactions such as Sonogashira, ${ }^{7}$ Suzuki $^{8}$ and Ullmann ${ }^{9}$ are examples of gold catalyzed organic reactions. However, among the different gold catalyzed reactions, Sonogashira reaction ${ }^{10}$ which is the coupling reaction of vinyl or aryl halides or triflates with terminal alkynes, have been studied under precise conditions. Both heterogeneous and homogeneous gold catalysts have been employed for Sonogashira reaction. Lambert and co-workers showed metallic Au nanoparticles supported on silica, $y$-alumina, $\mathrm{BaO}$, lanthana, and ceria have high reactivity in Sonogashira coupling reaction of iodobenzene with phenylacetylene whereas $\mathrm{Au}^{\prime}$ and $\mathrm{Au} \mathrm{u}^{\mathrm{III}}$ species were inert. ${ }^{7 \mathrm{a}}$ Despite that Echavarren and coworkers claim that trace quantities of palladium impurity is responsible in gold catalyzed Sonogashira reaction, ${ }^{7 b}$ Corma and coworkers proved that gold is intrinsically active species to perform the Sonogashira coupling reaction. ${ }^{7 \mathrm{e}-\mathrm{g}}$ Even with high efficiency and selectivity of reported gold catalyzed Sonogashira

[a] Mohammad GholinejadJahantab Ahmadi

Department

Department of Chemistry, Institute for Advanced Studies in Basic Sciences (IASBS), P. O. Box 45195-1159, Gavazang, Zanjan 45137-6731, Iran

E-mail: gholinejad@iasbs.ac.ir

[b] Carmen Najera

Departamento de Química Orgánica and Centro de Innovación en Química Avanzada (ORFEO-CINQA). Universidad de Alicante,

Apdo. 99, E-03080-Alicante, Spain

Email: cnajera@ua.es

Supporting information for this article is given via a link at the end of the document. coupling reaction, performing reactions at high temperatures (130-160 $\left.{ }^{\circ} \mathrm{C}\right)$ and limitation of reaction to only few aryl iodides are the most drawbacks of the reported methods. ${ }^{7}$ Despite the many palladium catalyzed Sonogashira reaction in the presence of copper co-catalyst, ${ }^{10-11}$ to the best of our knowledge there is no report on combination of copper and gold nanoparticles as a catalyst in Sonogashira coupling reaction. Now in this report, we introduce for the first time, immobilization of gold and $\mathrm{CuFe}_{2} \mathrm{O}_{4}$ nanoparticles on silica particles and its application as a magnetically separable dual catalyst in Sonogashira coupling reaction not only for aryl iodides but also for aryl bromides.

\section{Results and Discussion}

The stages of preparation of the catalyst are summarized in Scheme 1. The surface of silica particles was functionalized with thiol group using (3-mercaptopropyl)triethoxysilane $\left(\mathrm{SH} @ \mathrm{SiO}_{2}\right)$. The loading of organic group in $\mathrm{SH} @ \mathrm{SiO}_{2}$ was determined using theromogravimetric analysis (TGA) to be $1.2 \mathrm{mmol} \cdot \mathrm{g}^{-1}$ (Figure 1 , supporting information). In order to assemble $\mathrm{CuFe}_{2} \mathrm{O}_{4}$ nanoparticles, the prepared $\mathrm{CuFe}_{2} \mathrm{O}_{4} \mathrm{NPS}$ were functionalized with chloro atom using (3-chloropropyl)triethoxysilane. TGA confirmed presence of organic group on $\mathrm{CuFe}_{2} \mathrm{O}_{4}$. NPs with loading of $0.4 \mathrm{mmol} \cdot \mathrm{g}^{-1}$ (Figure 2, supporting information). The chloro functionalized $\mathrm{CuFe}_{2} \mathrm{O}_{4}\left(\mathrm{Cl} @ \mathrm{CuFe}_{2} \mathrm{O}_{4}\right)$ were assemble on thiol functionalized silica particles under refluxing toluene. The resulting $\mathrm{CuFe}{ }_{2} \mathrm{O}_{4} @$ silica was reacted with $\mathrm{HAuCl}_{4} \cdot 4 \mathrm{H}_{2} \mathrm{O}$ to produce final $\mathrm{Au} \cdot \mathrm{CuFe}{ }_{2} \mathrm{O}_{4} @$ Silica material. The loading of $\mathrm{Au}$ and $\mathrm{Cu}$ species in $\mathrm{Au} \cdot \mathrm{CuFe}_{2} \mathrm{O}_{4} @$ Silica were determined using ICP to be 0.12 and $0.4 \mathrm{mmol} \cdot \mathrm{g}^{-1}$, respectively.
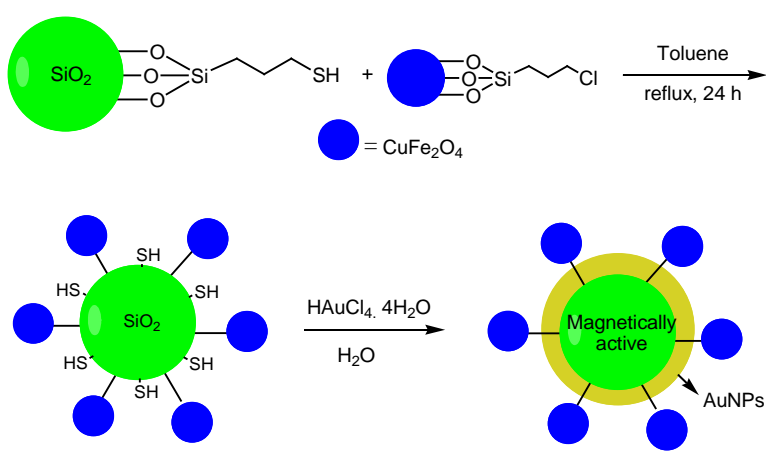

Scheme 1.Preparation of Au.CuFe ${ }_{2} \mathrm{O}_{4} @$ Silica. 
Silica microparticles were prepared by the Stober process using tetraethyl orthosilicate. ${ }^{12}$ SEM image confirmed formation of micro spherical particles in average size of $500 \mathrm{~nm}$ (Figure 1).

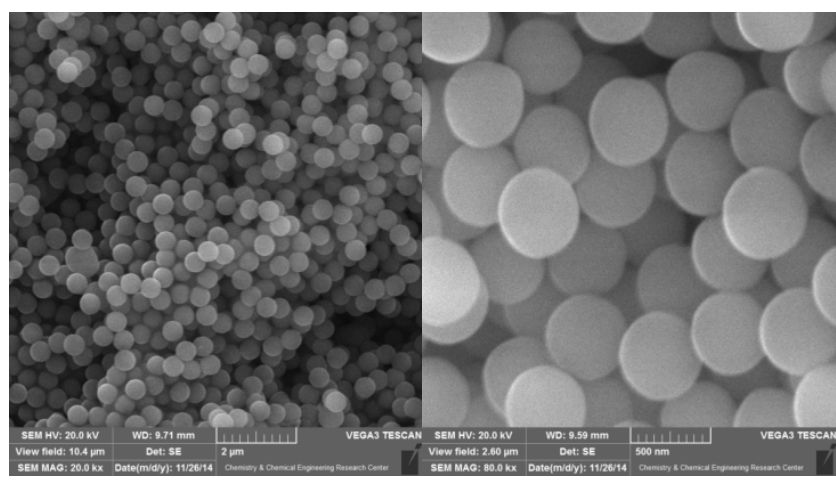

Figure 1.SEM images of prepared micro silica particles.

SEM image of prepared Au.CuFe ${ }_{2} \mathrm{O}_{4} @$ Silica in different magnification showed attachment of $\mathrm{CuFe}_{2} \mathrm{O}_{4}$ nanoparticles on thiol functionalized silica particles (Figure 2). Also, EDS analysis obtained from SEM confirmed presence of $\mathrm{Si}, \mathrm{Fe}, \mathrm{Cu}$ and $\mathrm{Au}$ species in the structure of prepared material (Figure 3).
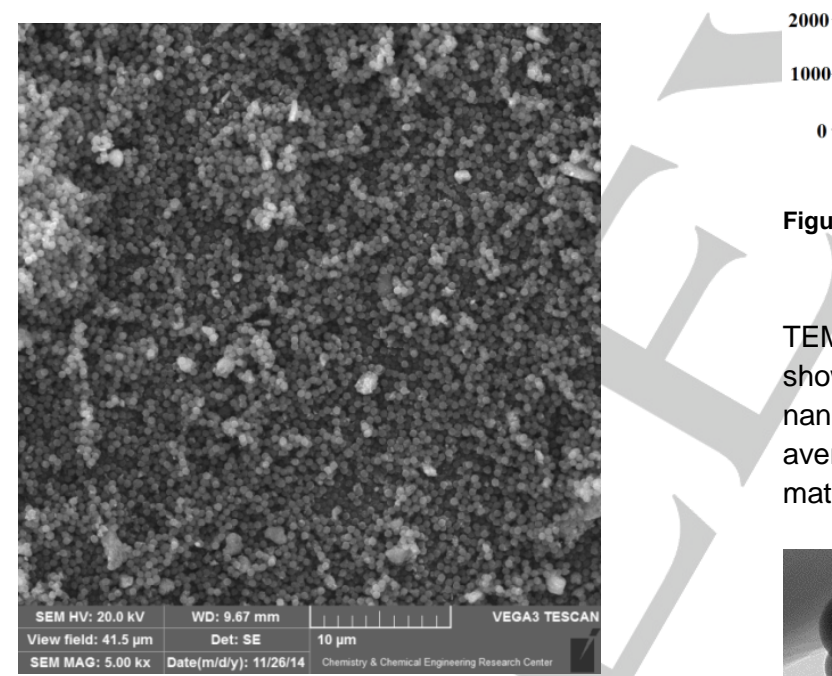

\begin{tabular}{r}
5000 \\
4000 \\
3000 \\
2000 \\
\hline 100 \\
\hline \\
0
\end{tabular}

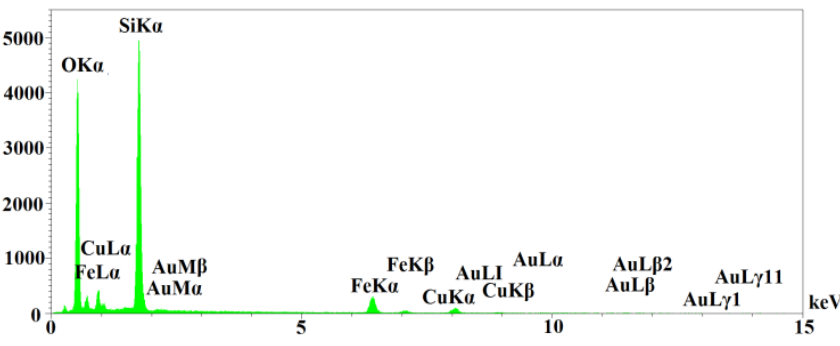

Figure 3.EDS spectrum of theAu.CuFe ${ }_{2} \mathrm{O}_{4} @$ Silica.

TEM images of $\mathrm{Au} . \mathrm{CuFe}_{2} \mathrm{O}_{4} @$ Silica in different magnification showed grafting of small size and mono-dispersed $\mathrm{Au}$ nanoparticle $(2-3 \mathrm{~nm})$ on silica surface. Also, $\mathrm{CuFe}_{2} \mathrm{O}_{4}$ with average size of $70 \mathrm{~nm}$ are observable in the surface of prepared material (Figure 4).
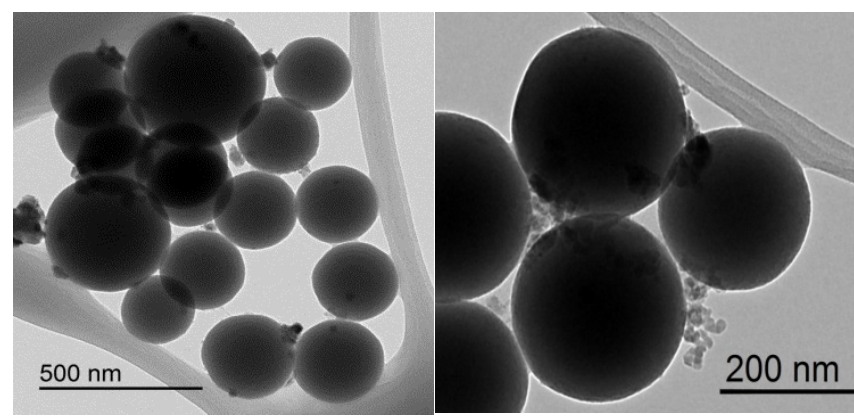


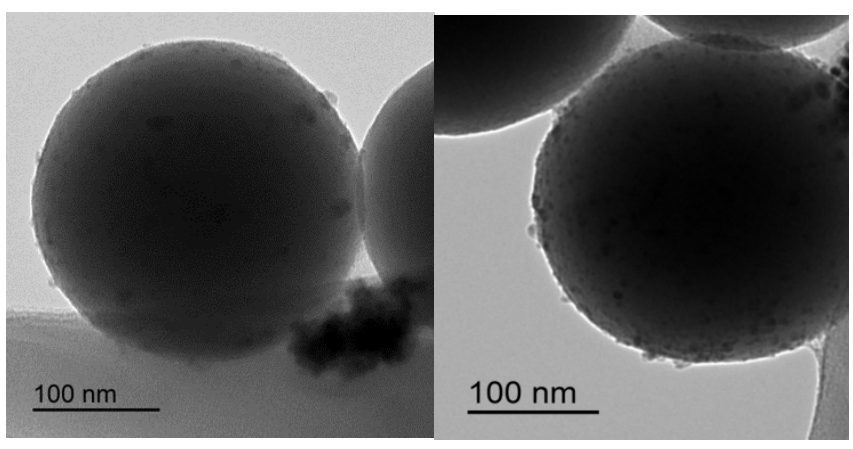

Figure 4. TEM images of the prepared Au·CuFe ${ }_{2} \mathrm{O}_{4} @$ Silica in different magnification.

X-ray diffraction (XRD) analysis of prepared catalyst showed presence of $\mathrm{CuFe}_{2} \mathrm{O}_{4}{ }^{13}$ nanoparticles by screening Bragg's reflections related in $2 \theta=18.3^{\circ}, 30.3^{\circ}, 35.6^{\circ}, 57.1^{\circ}, 62.98^{\circ}$ and Bragg's reflections related to metal gold ${ }^{14}$ in $2 \theta=38.2^{\circ}, 44.5^{\circ}$, $65.6^{\circ}$ and 78.6 as well as silica particles ${ }^{11} 2 \theta=22$ (Figure 5).

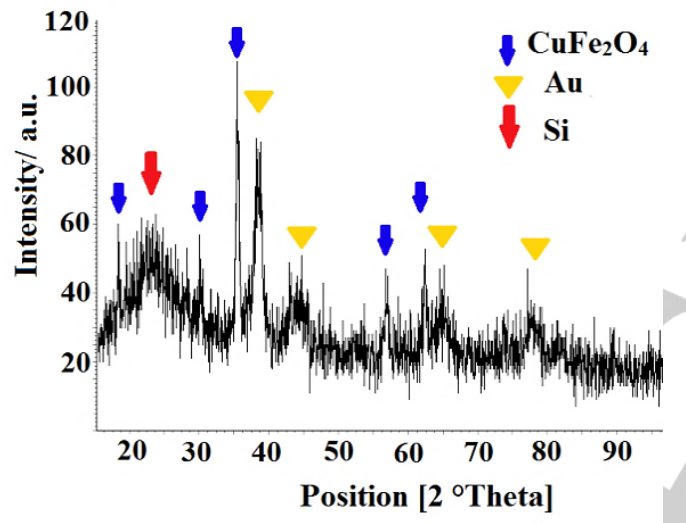

Figure 5.XRD pattern of the Au.CuFe ${ }_{2} \mathrm{O}_{4} @$ Silica.

In order to get information of oxidation state of Au nanoparticles, $X$-ray photoelectron spectrum (XPS) of the material was studied (Figure 6). As seen in Fig. 6, the $A u 4 f 7 / 2$ and $4 f 5 / 2$ bands with binding energies of 84.85 and 88.48 correspond to the $A u(0)$ is only comprising Au species in the material. ${ }^{15}$

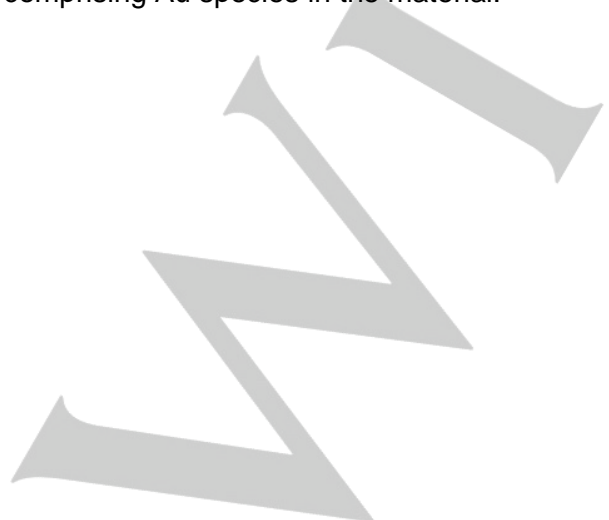

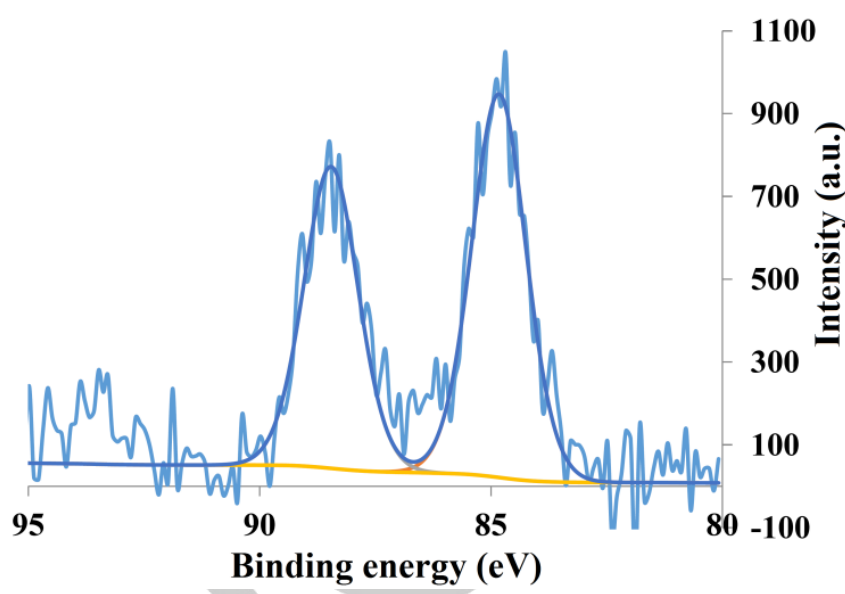

Figure 6. X-ray photoelectron spectroscopy (XPS) of the Au·CuFe ${ }_{2} \mathrm{O}_{4} @$ Silica.

The structure of Au.CuFe ${ }_{2} \mathrm{O}_{4} @$ Silica was further studied using EDX-mapp images obtained from SEM. Elemental maps confirm that $\mathrm{Au}, \mathrm{Cu}, \mathrm{Fe}$, and $\mathrm{Si}$ elements are presented in the structure (Figure 3, supporting information). Also, overlay EDX-mapp image showed that $\mathrm{Au}$ and Fe species are separately located in the surface of silica particles (Figure 7).

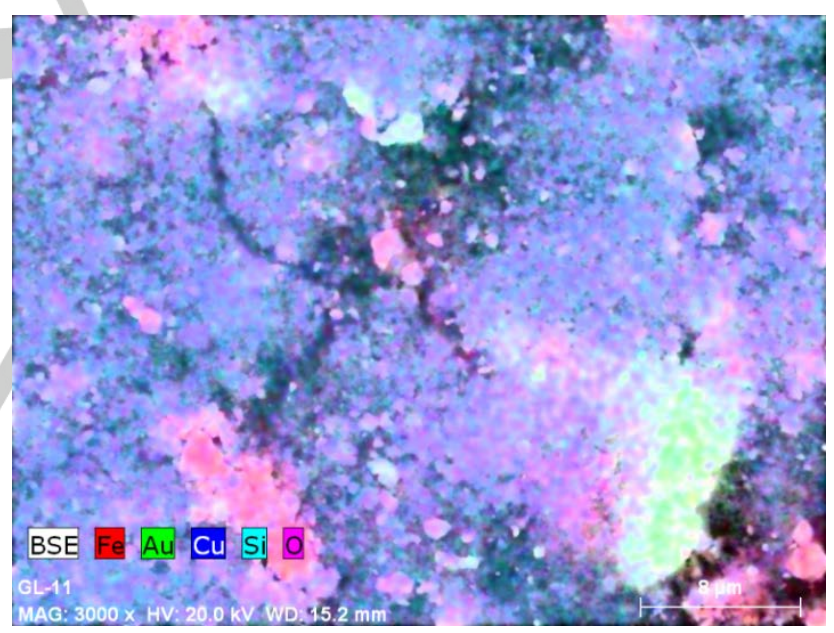

Figure 7.Overlay EDX-mapp image of $\mathrm{Au} \cdot \mathrm{CuFe}_{2} \mathrm{O}_{4} @$ Silica

We have tested application of prepared material in Sonogashira coupling and reaction of iodobenzene with phenylacetylene was selected as a model reaction. Study of the reaction in $N, N$ dimethylacetamide (DMA) as solvent using different mol\% of $\mathrm{Au}$ at $125{ }^{\circ} \mathrm{C}$ showed better results using $t$-BuOK as a base than $\mathrm{K}_{2} \mathrm{CO}_{3}$ in the presence of $0.9 \mathrm{~mol} \%$ catalyst loading (Table 1 , entries 1 and 2). When different bases such as $\mathrm{K}_{3} \mathrm{PO}_{4}$ and DABCO awere assayed lower yields were obtained (Table 1, entries 3 and 4). The reaction was performed at $125^{\circ} \mathrm{C}$ using $t$ BuOK $0.5 \mathrm{~mol} \%$ of catalyst loading with similar yield (Table 1 , compare entries 2 and 5). Lowing the temperature to $115^{\circ} \mathrm{C}$ and 
$t$-BuOK or $\mathrm{K}_{2} \mathrm{CO}_{3}$ as base in DMA a $95 \%$ or $6 \%$ yield were obtained, respectively (Table 1 , entries 6 and 7). At this temperature a with $0.5 \mathrm{~mol} \%$ catalyst loading the same $95 \%$ yield of tolane A was obtained and not formation of diyne B was detected (Table 1, entry 8). However, using 0.3 or $0.1 \mathrm{~mol} \%$ catalyst loading the yield decreased to $46 \%$ or $19 \%$, respectively (Table 1, entries 9 and 10). Study of reaction using $t$-BuOK at $115^{\circ} \mathrm{C}$ in other solvents such as PEG, DMF, water and xylenes gave lower yields for the reaction even working with $0.9 \mathrm{~mol} \%$ of catalyst (Table 1, entries 11-14). Further studies decreasing the reaction temperature to $105^{\circ} \mathrm{C}$ and using $t$-BuOK as a base and $0.9 \mathrm{~mol} \%$ Au loading cause decrease in reaction yields (Table 1, entry 15). Therefore $t$-BuOK as a base, DMA as a solvent and $0.5 \mathrm{~mol} \%$ of $\mathrm{Au}$ at $115^{\circ} \mathrm{C}$ was selected as optimized reaction conditions (Table 1, entry 8). It was worth mentioning that using $1.6 \mathrm{~mol} \%$ of $\mathrm{CuFe}_{2} \mathrm{O}_{4} @ \mathrm{SiO}_{2}$ in the absence of $\mathrm{Au}$ for model reaction under found optimized condition showed only $28 \%$ conversion (determined by $\mathrm{GC}$ ). Also, using $\mathrm{Au} @ \mathrm{SiO}_{2}$ in the absence of $\mathrm{CuFe}_{2} \mathrm{O}_{4}$ showed $53 \%$ conversion to desired product.

Table 1. Optimization of the reaction conditions for the reaction of iodobenzene with phenylacetylene ${ }^{[a]}$

\begin{tabular}{|c|c|c|c|c|c|c|}
\hline Entry & (Cat.mol\%) & Base & Solvent & $\begin{array}{c}\text { Temp } \\
\left({ }^{\circ} \mathrm{C}\right)\end{array}$ & $\begin{array}{c}\text { Yield A } \\
{[\%]^{[b]}}\end{array}$ & $\begin{array}{c}\text { Yield B } \\
{[\%]^{[b]}}\end{array}$ \\
\hline 1 & 0.9 & $\mathrm{~K}_{2} \mathrm{CO}_{3}$ & DMA & 125 & 81 & 6 \\
\hline 2 & 0.9 & $t$-BuOK & DMA & 125 & 96 & 1 \\
\hline 3 & 0.9 & $\begin{array}{c}\mathrm{K}_{3} \mathrm{PO}_{4} . \\
3 \mathrm{H}_{2} \mathrm{O}\end{array}$ & DMA & 125 & 66 & \\
\hline 4 & 0.9 & $\begin{array}{c}\text { DABC } \\
0\end{array}$ & DMA & 125 & 16 & \\
\hline 5 & 0.5 & $t$-BuOK & DMA & 125 & 93 & 2 \\
\hline
\end{tabular}

\begin{tabular}{ccccccc}
6 & 0.9 & $t$-BuOK & DMA & 115 & 95 & 3 \\
7 & 0.9 & $\mathrm{~K}_{2} \mathrm{CO}_{3}$ & DMA & 115 & 6 & 33 \\
8 & 0.5 & $t$-BuOK & DMA & 115 & 95 & 0 \\
9 & 0.3 & $t$-BuOK & DMA & 115 & 46 & 0 \\
10 & 0.1 & $t$-BuOK & DMA & 115 & 19 & 3 \\
11 & 0.9 & $t$-BuOK & PEG & 115 & 12 & 0 \\
12 & 0.9 & $t$-BuOK & DMF & 115 & 71 & 11 \\
13 & 0.9 & $t$-BuOK & H ${ }_{2} \mathrm{O}$ & 115 & 5 & 2 \\
14 & 0.9 & $t$-BuOK & Xylenes & 115 & 1 & 2 \\
15 & 0.9 & $t$-BuOK & DMA & 105 & 40 & 0 \\
\hline
\end{tabular}

[a] Reaction conditions: iodobenzene $(1 \mathrm{mmol})$, phenylacetylene $(1.5 \mathrm{mmol})$, base $(1.5 \mathrm{mmol})$, catalyst (see column) in $2 \mathrm{~mL}$ of solvent.

These reaction conditions were applied for the Sonogashira reactions of structurally different aryl halides. In the case of aryl iodides containing electron-donating groups such as 4-Me, 4$\mathrm{OMe}$ as well as electron-withdrawing groups such as $4-\mathrm{NO}_{2}$, 4$\mathrm{Cl}, 4-\mathrm{F}, 4-\mathrm{CN}$ reacted with phenylacetylene and4-ethynyltoluene were proceed efficiantly and desired coupling products were obtained in 73-98 \% isolated yields. Reactions of 2iodothiophene as a heterocyclic aryl halide with both phenyl acetylene and4-ethynyltoluene proceed very effectivelly and afford products in excellent yields (Table 2, entries 10,11). Furthermore reaction of less reactive and sterically hindered 2iodophenol with phenylacetylene was proceed very well and disered coupling product was obtained without formation of any ring-closing 2-phenylbenzofuran product (Table 2, entry 13). However, study of reaction of 1-bromo-4-nitrobenzene with phenylacetylene under optimized reaction conditions showed formation of product with $67 \%$ yield. Therfore reaction temperature was increased to $130{ }^{\circ} \mathrm{C}$ and Sonogashira reaction of differentet aryl bromides were studied under efficient reaction conditions (Table 2, entries 14-19).

Table 2. . The reactions of structurally different aryl iodides and bromides with alkynes in the presence of $\mathrm{Au}^{\mathrm{C}} \mathrm{CuFe}_{2} \mathrm{O}_{4} @ \mathrm{Silica}^{[\mathrm{a}]}$

$$
\mathrm{Ar}^{1} \mathrm{X}+\mathrm{Ar}^{2}=\frac{\begin{array}{c}
\mathrm{Au}^{2} \mathrm{CuF}_{2} \mathrm{O}_{4} @ \mathrm{SiO}_{2} \\
(0.5 \mathrm{~mol} \%)
\end{array}}{\substack{t-\mathrm{BuOK}, \mathrm{DMA} \\
115^{\circ} \mathrm{C}}} \mathrm{Ar}^{1}=\mathrm{Ar}^{2}
$$

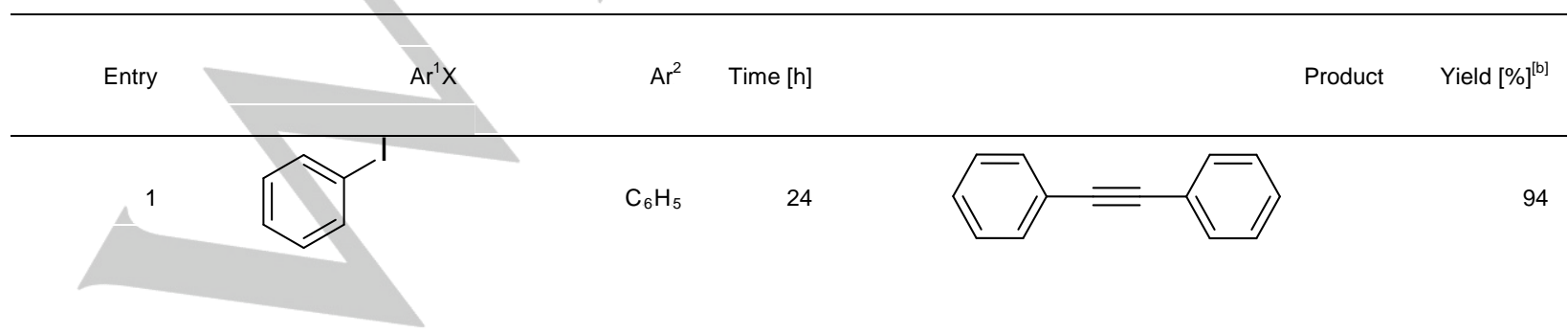




$$
2
$$<smiles>Cc1ccc(I)cc1</smiles><smiles>COc1ccc(I)cc1</smiles><smiles>N#Cc1ccc(I)cc1</smiles>

5<smiles>COc1ccc(I)cc1</smiles>

6<smiles>Fc1ccc(I)cc1</smiles>

7<smiles>Clc1ccc(I)cc1</smiles>

8<smiles>Fc1ccc(I)cc1</smiles>

9<smiles>Clc1ccc(I)cc1</smiles>

10

11

13<smiles>Ic1cccs1</smiles>

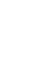<smiles>Ic1cccs1</smiles><smiles>Ic1ccccc1</smiles><smiles>Oc1ccccc1I</smiles>

14<smiles>O=[N+]([O-])c1ccc(Br)cc1</smiles>

15<smiles>N#Cc1ccc(Br)cc1</smiles>

16<smiles>Brc1cncnc1</smiles>

17

$\mathrm{C}_{6} \mathrm{H}_{5}$

48<smiles>Cc1ccc(C#Cc2ccccc2)cc1</smiles>

$\mathrm{C}_{6} \mathrm{H}_{5} \quad 24$<smiles>COc1ccc(C#Cc2ccccc2)cc1</smiles>

$\mathrm{C}_{6} \mathrm{H}_{5}$

24<smiles>N#Cc1ccc(C#Cc2ccccc2)cc1</smiles>

4- $\mathrm{MeC}_{6} \mathrm{H}_{4}$ 24

$\mathrm{C}_{6} \mathrm{H}_{5}$

24

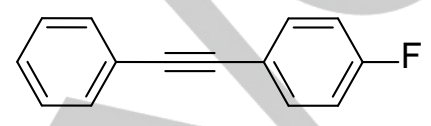

$\mathrm{C}_{6} \mathrm{H}_{5}$

24

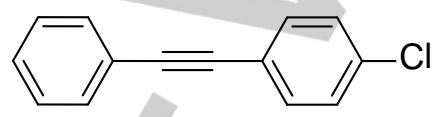

4- $\mathrm{MeC}_{6} \mathrm{H}_{4}$

24<smiles>Cc1ccc(C#Cc2ccc(F)cc2)cc1</smiles>

4- $\mathrm{MeC}_{6} \mathrm{H}_{4}$<smiles>Cc1ccc(C#Cc2ccc(Cl)cc2)cc1</smiles>

$\mathrm{C}_{6} \mathrm{H}_{5}$

24<smiles>C(#Cc1cccs1)c1ccccc1</smiles>

4- $\mathrm{MeC}_{6} \mathrm{H}_{4}$

24

4- $\mathrm{MeC}_{6} \mathrm{H}_{4}$

24

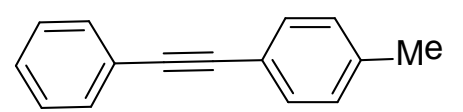

$\mathrm{C}_{6} \mathrm{H}_{5}$

24<smiles>Oc1ccccc1C#Cc1ccccc1</smiles>

48<smiles>O=[N+]([O-])c1ccc(C#Cc2ccccc2)cc1</smiles>

$\mathrm{C}_{6} \mathrm{H}_{5} \quad 48$

$\begin{array}{ll}\mathrm{C}_{6} \mathrm{H}_{5} \quad 48 & 48\end{array}$<smiles>N#Cc1ccc(C#Cc2ccccn2)cc1</smiles>

48

4- $\mathrm{MeC}_{6} \mathrm{H}_{4}$<smiles>Cc1ccc(C#Cc2cncnc2)cc1</smiles>

$\mathrm{C}_{6} \mathrm{H}_{5} \quad 48$

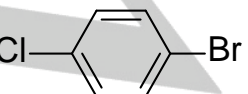

97

95

90

$97^{[\mathrm{c}]}$

$100^{[c]}$

$82^{[c]}$ 
19

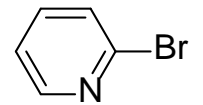

$\mathrm{C}_{6} \mathrm{H}_{5}$

48 $88^{[\mathrm{c}]}$

[a] Reaction conditions: $\operatorname{ArX}(1 \mathrm{mmol})$, alkyne (1.5 mmol), $t$-BuOK $(1.5 \mathrm{mmol})$, catalyst $(40 \mathrm{mg}$ catalyst containing $0.5 \mathrm{~mol} \% \mathrm{Au})$ at $115{ }^{\circ} \mathrm{C}$ in $\mathrm{DMA}(2 \mathrm{~mL})$. [b] Isolated product after column chromatography. [c] The reaction was performed at $130^{\circ} \mathrm{C}$.

The proposed mechanism for the reaction is in accordance with Corma and col. DFT calculations. ${ }^{7 g, h}$ In the case of $\mathrm{Au}$ NPS it can be formed an adsorption complex with iodobenzene in which the iodine atom is directly bonded to the $\mathrm{Au}$ atom, after transfer of the I atom to Au finally the Ph group is bonded to another $\mathrm{Au}$ atom. It means that the rupture of the $\mathrm{C}-\mathrm{I}$ bond by $\mathrm{Au}$ NPs is feasible. ${ }^{7 \mathrm{~g}}$ Moreover, phenylacetylenecan be absorbed in activated $\mathrm{Au}^{\delta+}$ species which helps in the $\mathrm{C}-\mathrm{H}$ activation process. ${ }^{7 \mathrm{~h}}$ In the case of $\mathrm{Cu}$ the most probably interaction is the formation of a copper acetylide with the participation of the base accelerating the reaction. In addition, in the Cu-catalyzed Sonogashira reaction aryl iodides can also react with acetylenes, it means that also $\mathrm{Cu}$ can cleave the $\mathrm{C}$-I bond.We think that both $\mathrm{Au}$ and $\mathrm{Cu}$ species have positive effect in $\mathrm{C}-\mathrm{H}$ bond activation of alkyne and $\mathrm{C}-\mathrm{X}$ activation af aryl halides. Initial $\pi$-activitation of the triple $\mathrm{C}-\mathrm{C}$ bond by both $\mathrm{Au}$ and $\mathrm{Cu}$ can also participate in the reaction.

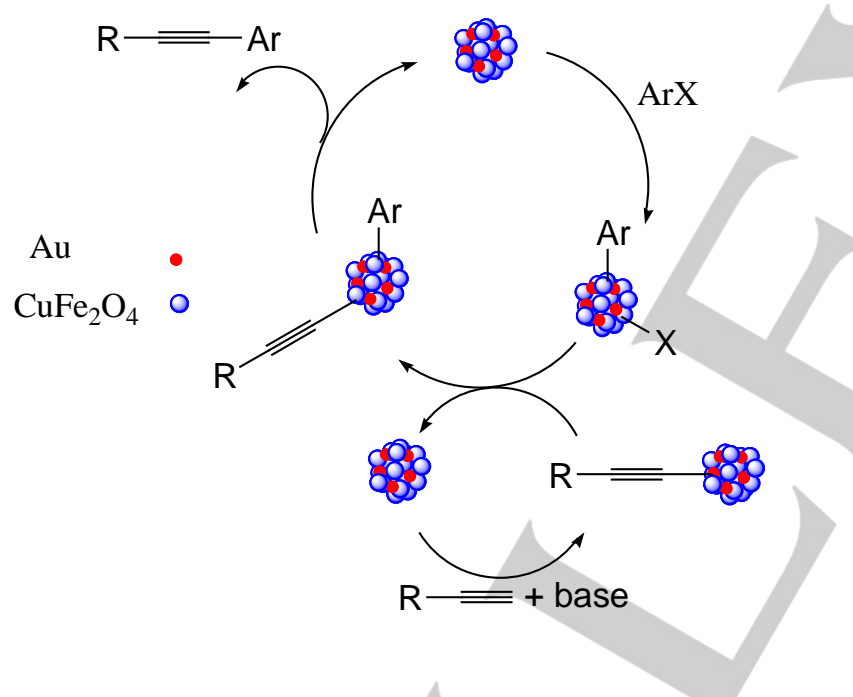

Scheme 2. Proposed reaction mechanism using Au·CuFe ${ }_{2} \mathrm{O}_{4} @$ Silica

Finally we have studied the recyclable property of prepared Au.CuFe ${ }_{2} \mathrm{O}_{4} @ \mathrm{SiO}_{2}$ catalyst for the reaction of iodobenzene with phenylacetylene. For this purpose after $1 \mathrm{~d}$ reaction time, the resulting suspension was subjected to external magnet and after washing and drying was used for another reaction batch. Using this process, catalyst was successfully recycled for four consecutive runs with small decrease in activity (Figure 8). TEM image of recovered catalyst after fourth run showed that the catalyst structure was preserved during these processes (Figure 9).

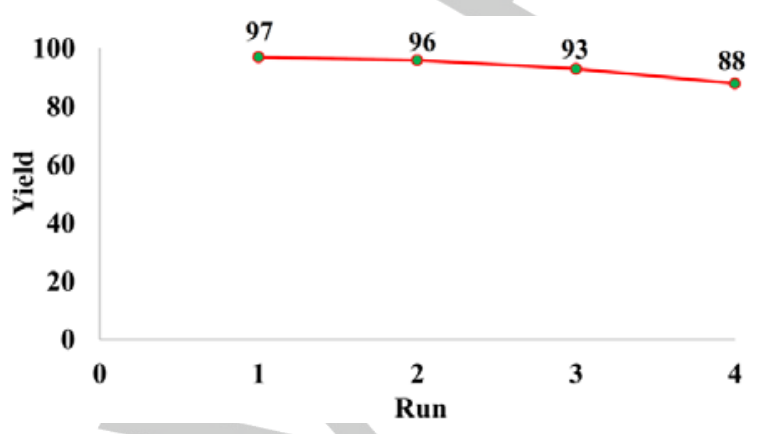

Figure 8. Recycling of catalyst for the reaction of iodobenzene with phenylacetylene.

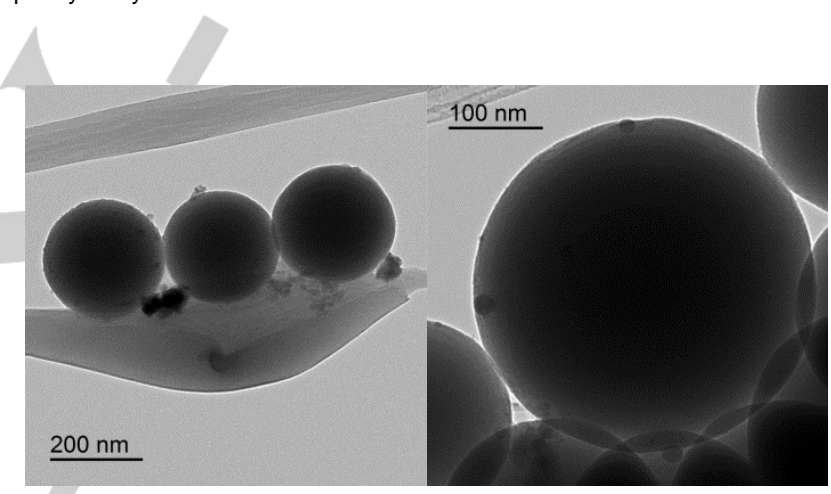

Figure 9. TEM images of recoverd catalyst after fourth run.

\section{Conclusions}

The excellent catalytic activity of silica supported gold and copper ferrite nanoparticles (NPs) for the alkynylation not only of aryl iodides but also of aryl bromides has been demonstrated. The cooperative effect of both metals, gold and copper versus only copper in the supported catalyst has been clearly demonstrated. The use of $t$-BuOK as base and DMA as solvent at $115{ }^{\circ} \mathrm{C}$ for iodides and $130{ }^{\circ} \mathrm{C}$ for bromides allowed the synthesis of internal alkynes in excellent yields with a very low $\mathrm{Au} \cdot \mathrm{CuFe}_{2} \mathrm{O}_{4} @ \mathrm{SiO}_{2}$ loading (0.5 mol\%). The inorganic support facilitates the recyclability and reusability of this heterogeneous catalyst by a simple external magnet.

\section{Experimental Section}

Synthesis of $500 \mathrm{~nm}$ silica particles 
The spherical silica particles were synthesized according a procedure reported in the literature, [12] which will briefly be explained as following. A mixture of deionized $\mathrm{H}_{2} \mathrm{O}(3.4 \mathrm{~mL}), \mathrm{NH}_{3}(3.4 \mathrm{~mL})$ and isopropanol $(86.8 \mathrm{~mL})$ was stirred for $10 \mathrm{~min}$ at room temperature. To the resulting mixture, $\mathrm{Si}(\mathrm{OEt})_{4}(6.4 \mathrm{~mL})$ were added dropwise. After $24 \mathrm{~h}$, the silica particles were centrifugally separated from the suspension and washed with water and ethanol for four times, and then dried in oven at $60^{\circ} \mathrm{C}$.

\section{Synthesis of (3-mercaptopropyl)triethoxysilane functionalized silica} particles (SH@SiO 2 )

The above described synthesized silica particles $(1.2 \mathrm{~g})$ were sonicated in dry toluene $(40 \mathrm{~mL})$ for $30 \mathrm{~min}$. Then, 3-mercaptopropyltriethoxysilane $(1.8 \mathrm{~mL}, 7.6 \mathrm{mmol})$ was added and the resulting mixture was refluxed for $24 \mathrm{~h}$ under argon atmosphere. Then, the (3mercaptopropyl)triethoxysilane functionalized silica particles were separated using centrifugation and washed with $\mathrm{EtOH}(3 \times 10 \mathrm{~mL})$ and dried in oven at $60^{\circ} \mathrm{C}$ for $24 \mathrm{~h}$.

\section{Synthesis of (3-chloropropyl)trimethoxysilane functionalized} $\mathrm{CuFe}_{2} \mathrm{O}_{4}$ particles $\mathrm{Cl} @ \mathrm{CuFe}_{2} \mathrm{O}_{4}$

Synthesized $\mathrm{CuFe}_{2} \mathrm{O}_{4} \mathrm{NPS}$ (500 mg) were dispersed in dry toluene (15 $\mathrm{mL}$ ) for 30 min using ultrasound assistance. To the resulting solution, 3chloropropyltrimethoxysilane $(0.55 \mathrm{~mL}, 3 \mathrm{mmol})$ was added and mixture was refluxed for $24 \mathrm{~h}$ under argon atmosphere. The (3chloropropyl)trimethoxysilane functionalized CuFe2O4NPs was subjected to magnetic separation, and was washed sequentially with $\mathrm{EtOH}(3 \times 20 \mathrm{~mL})$ and dried under vacuum for $24 \mathrm{~h}$.

\section{Assemble of $\mathrm{Cl} @ \mathrm{CuFe}_{2} \mathrm{O}_{4} \mathrm{NPs}$ on $\mathrm{SH} @ \mathrm{SiO}_{2}$}

$\mathrm{Cl} @ \mathrm{CuFe}_{2} \mathrm{O}_{4} \quad(100 \mathrm{mg})$ and $\mathrm{SH} @ \mathrm{SiO}_{2}$ particles (500 mg) were dispersed separately in toluene $(15 \mathrm{~mL})$ for $30 \mathrm{~min}$ and then mixed together. To the resulting mixture, $\mathrm{Et}_{3} \mathrm{~N}(0.28 \mathrm{~mL}, 2 \mathrm{mmol})$ was added and reaction mixture refluxed for $24 \mathrm{~h}$ under argon atmosphere. Then, the mixture was subjected to magnetic separation and the isolated $\mathrm{CuFe}_{2} \mathrm{O}_{4} @ \mathrm{SiO}_{2} \mathrm{NPs}$ were washed sequentially with $\mathrm{CH}_{2} \mathrm{Cl}_{2}(2 \times 10 \mathrm{~mL})$ and dried under vacuum for $24 \mathrm{~h}$

\section{Preparation of $\mathrm{Au} \cdot \mathrm{CuFe}_{2} \mathrm{O}_{4} @ \mathrm{SiO}_{2}$}

To mixture containingpolyvinylpyrrolidone(40mg) and $\mathrm{HAuCl}_{4} .4 \mathrm{H}_{2} \mathrm{O}(80$ $\mathrm{mg}, 0.19 \mathrm{mmol})$ in $\mathrm{H}_{2} \mathrm{O}(5 \mathrm{~mL})$ a solution of $\mathrm{NaBH}_{4}(75 \mathrm{mg}, 2 \mathrm{mmol})$ in $\mathrm{H}_{2} \mathrm{O}(3 \mathrm{~mL}$ ) was added dropwise. The resulting mixture was added tothe already sonicatedCuFe ${ }_{2} \mathrm{O}_{4} @ \mathrm{SiO}_{2}\left(1 \mathrm{gr}\right.$ in $10 \mathrm{~mL}$ of $\left.\mathrm{H}_{2} \mathrm{O}\right)$. The mixture was stirred for $24 \mathrm{~h}$ at room temperatureunder argon atmosphere. Then, the final $\mathrm{Au} \cdot \mathrm{CuFe}_{2} \mathrm{O}_{4} @ \mathrm{SiO}_{2}$ catalyst was separated magnetically and was washed sequentially using $\mathrm{H}_{2} \mathrm{O}(20 \mathrm{~mL})$ and $\mathrm{CH}_{2} \mathrm{Cl}_{2}(2 \times 10 \mathrm{~mL})$ and dried in oven at $60{ }^{\circ} \mathrm{C}$ for $24 \mathrm{~h}$.

\section{General procedure for Sonogashira coupling reaction of aryl halides}

The catalyst (40 mg containing $0.5 \mathrm{~mol} \% \mathrm{Au}$ and $1.6 \mathrm{~mol} \% \mathrm{Cu}$ ), aryl halides (1 mmol), alkyne (1.5 mmol), $t$ - BuOK (2 mmol) and DMA (2 mL) were added to flask equipped with a stir bar under argon atmosphere. The reaction mixture was stirred for the appropriate reaction time at 115$130{ }^{\circ} \mathrm{C}$. The progress of the reactions was monitored using gas chromatography. After completion of reaction, $\mathrm{H}_{2} \mathrm{O}(2 \mathrm{~mL})$ was added to reaction mixture and the crude product was extracted using ethyl acetate $(3 \times 5 \mathrm{~mL})$. The combined organic extracts were dried over $\mathrm{Na}_{2} \mathrm{SO}_{4}$ and concentrated under reduced pressure. The resulting crude product was further purified by column chromatography using n-hexane and ethyl acetate as eluents.

Typical procedure for the recycling of catalyst for the reaction of iodobenzene and phenylacetylene

After completion of reaction of iodobenzene with phenylacetylene reaction mixture was subjected to magnetic separation and catalyst was separated. The catalyst can isolate from reaction mixture completely during $10 \mathrm{~min}$ (Figure 4, supporting information). Then, isolated catalyst was washed with diethyl ether and after drying was used for another batch of the reaction.

\section{Acknowledgements}

The authors are grateful to Institute for Advanced Studies in Basic Sciences (IASBS) Research Council,Iran National Science Foundation (INSF-Grant number of 94010666) and the Spanish Ministerio de Economia y Competitividad (MINECO) (projects CTQ2013-43446-P and CTQ2014-51912-REDC), FEDER, the GeneralitatValenciana (PROMETEOII/2014/017)and the University of Alicante for financial support.

Keywords:Nanoparticles $\bullet$ gold $\bullet$ copper ferrite $\bullet$ Sonogashira -Magnetic

[1] a) M. Kokate, S. Dapurkar, K. Garadkar, A. Gole, J. Phys. Chem C2015, 119 14214-14223; b) R. H. Adnan, G. G. Andersson, M. I. J. Polson, G. F. Methad, V. B. Golovko, Catal. Sci. Technol.2015, 5 1323-1333; c) E. M. de Moura, M. A. S. Garcia, R. V. Gonçalves, P. K. Kiyohara, R. F. Jardim, Liane M. Rossi, RSC Adv.2015, 5, 1503515041; d) S. Rautiainen, O. Simakova, H. Guo, A.-R. Leino, K. Kordás, D. Murzin, Markku Leskelä, T. Repo, Appl. Catal. A: Gen. 2014, 485, 202-206; e) L. Li, L. Dou, H. Zhang, Nanoscale2014, 6, 3753-3763; f) D. I. Enache, J. K. Edwards, P. Landon, B. Solsona-Espriu, A. F. Carley, A. A. Herzing, M. Watanabe, C. J. Kiely, D. W. Knight, G. J. Hutchings, Science 2006, 311, 362-365; g) H. Tsunoyama, H. Sakurai, Y. Negishi T. Tsukuda, J. Am. Chem.Soc. 2005, 127, 9374-9375; h) B. Guan, D. Xing, G. Cai, X.Wan, N. Yu, Z. Fang, L. Yang, Z. Shi, J. Am. Chem. Soc. 2005, 127, 18004-18005; i) H. Miyamura, R. Matsubara, Y Miyazaki, S. Kobayashi, Angew. Chem. Int. Ed. 2007, 46, 4151-4154.

[2] a) A. S. K. Hashmi, I. Braun, M. Rudolph, F. Rominger Organometallics2012, 31, 644-661; b) T. Ishida, S. Aikawa, Y. Mise, R. Akebi, A. Hamasaki, T. Honma, H. Ohashi, T. Tsuji, Y. Yamamoto, M. Miyasaka, T. Yokoyama, M. Tokunaga, ChemSusChem2015, 8, 695701; c) Z. Shi, C. He, J. Am. Chem. Soc. 2004, 126, 13596-13597; d) C. Nevado, A. M. Echavarren, Chem. Eur. J. 2005, 11, 3155-3164.

[3] a) A. Comas-Vives, G. Ujaque, J. Am. Chem. Soc.2013, 135, 12951305; b) F. Cárdenas-Lizana, M. A. Kean, J. Mat. Sci. 2013, 48, 543 564; c) M. Pan, A. J. Brush, Z. D. Pozun, H. C. Ham, W.-Y. Yu, G. Henkelman, G. S. Hwanga, C. B. Mullins, Chem. Soc. Rev.2013, 42, 5002-5013; d) T. Mitsudome, K. Kaneda, Green Chem.2013, 15, 2636-2654.

[4] Alcaide, P. Almendros, J. M. Alonso, Org. Biomol. Chem.2011, 9, 4405-4416.

[5] a) R. E. M. Brooner, B. D. Robertson, R. A. Widenhoefer, Organometallics2014, 33, 6466-6473; b) K. Speck , K. Karaghiosoff, T. Magauer, Org. Lett.2015, 17, 1982-1985. 
[6] a) J. Ni, L. He, Y.-M.Liu, Y. Cao, H.-Y.He, K.-N.Fan, Chem. Commun.2011, 47, 812-814; b) T. Mitsudome, A. Noujima, Y. Mikami, T. Mizugaki, K. Jitsukawa, K. Kaneda, Chem. Eur. J.2010, 16, 1181811821.

[7] a) S. K. Beaumont, G. Kyriakou, R. M. Lambert, J. Am. Chem. Soc. 2010, 132, 12246-12248; b) T. Lauterbach, M. Livendahl, A. Rosellon P. Espinet, A. M. Echavarren, Org.Lett. 2010, 12, 3006-3009; c) S. Sisodiya, L. R. Wallenberg, E. Lewin, O. F. Wendt, Appl. Cat. A Genera/2015, 503, 69-76; d) G. Li, D.-E. Jiang, C. Liu, C. Yu, R. Jin J.Catal. 2013, 306, 177-183; e) C. Gonzalez-Arellano, A. Abad, A Corma, H. Garcia,M. Iglesias, F. Sánchez, Angew. Chem. Int. Ed. 2007 46, 1536-1538; f) A. Corma, R. Juarez, M. Boronat, F. Sánchez, M. Iglesias and H. Garcia, Chem. Commun.2011, 47, 1446-1448; g) M. Boronat, D. Combita, P. Concepción, A. Corma, H. García, R. Juarez, S. Laursen, J. de D. López-Castro, J. Phys. Chem. C 2012, 116 24855-24867; h)P. Li, L. Wang, M. Wang, and F. You, Eur. J. Org. Chem. 2008, 5946-5951; i) D. Qian, J. Zhang, Beilstein J Org Chem. 2011; 7: 808-812.

[8] a) D. Shah, H. Kaur, J. Mol. Catal. A: Chem.2014, 381, 70-76; b) D.K. Dumbre, P.N. Yadav, S.K. Bhargava, V.R. Choudhary, J. Catal. 2015 301, 134-140; c) N. Hoshiya, S. Shuto, M. Arisawa, Adv. Synth. Catal. 2011, 353, 743-748; d) C. González-Arellano, A. Corma, M. Iglesias, F. Sánchez, J. Catal. 2006, 238, 497-501; e) J. Han, Y. Liu, R. Guo, J. Am. Chem. Soc.2009, 131, 2060-2061.
[9] a) A. Monopoli, P. Cotugno, G. Palazzo, N. Ditaranto, B. Mariano, N Cioffi, F. Ciminale, A. Nacci, Adv. Synth.Catal.2012, 354, 2777-2788 b) K. Layek, H. Maheswaran and M. L. Kantam, Catal. Sci. Technol. 2013, 3, 1147-1150; c) S. KazemiMovahed, M. Fakharian, M. Dabiri, A Bazgir, RSC Adv. 2014, 4, 5243-5247; d) M. Dabiri, M. Shariatipour, S KazemiMovahed, S. Bashiribod, RSC Adv. 2014, 4, 39428-39434.

[10] a) R. Chinchilla, C. Nájera, Chem. Rev.2007, 107, 874-922; b) H. Doucet, J.-C. Hierso, Angew. Chem. Int. Ed. 2007, 46, 834-871; c) H Plenio, Angew. Chem. Int. Ed. 2008, 47, 6954-6956; d) N. M. Jenny, M. Mayo, T. R. Eaton, Eur. J. Org. Chem. 2011, 4965-4983; e) R. Chinchilla, C. Nájera, Chem. Soc. Rev. 2011, 40, 5084-5121; f) R. Chinchilla, C. Nájera, Chem. Rev.2014, 114, 1783-1826.

[11] M. Gholinejad, J. Ahmadi, ChemPlusChem2015, 80, 973-979.

[12] X.-D. Wang, Z.-X. Shen, T. Sang, X.-B. Cheng, M.-F.Li, L.-Y.Chen, Z.-S Wang, J. Colloid Interface Sci. 2010, 341, 23-29.

[13] M. Gholinejad, H. Firouzabadi, New J. Chem. 2015, 39, 5953-5959.

[14] a) V. C. Verma, S. K. Singh, R. Solanki, R. Prakash, Nanoscale Res. Lett.2011, 6, 16-22; b) S. S. Shankar, A. Ahmad, R. Pasricha; M. Sastry, J. Mater. Chem. 2003, 13, 1822-1826.

[15] a) Y. Xue, X. Li, H. Li, W. Zhang, Nature Commun.2014, 5, 4348; b) B. Karimi, M. Gholinejad, M. Khorasani, Chem. Commun. 2012, 48, 89618963 
Layout 1:

\section{FULL PAPER}

$\mathrm{Au}$ and $\mathrm{CuFe}_{2} \mathrm{O}_{4}$ NPs supported on silica as an efficient catalyst for Sonogashira reaction
Mohammad Gholinejad, ${ }^{*}[a]$ Jahantab Ahmadi, ${ }^{[a]}$ Carmen Nájera* ${ }^{[b]}$

Page No. - Page No.

Silica Microparticles Supported Gold and Copper Ferrite Nanoparticles: A Magnetically Recyclable Bimetallic Catalyst for Sonogashira Reaction

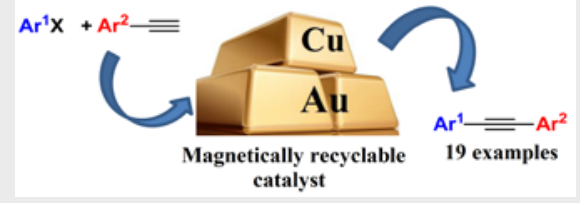

